\title{
Comparison of Open-Cell Stent and Closed-Cell Stent for Treatment of Central Vein Stenosis or Occlusion in Hemodialysis Patients
}

\author{
Chae Hoon Kang, ${ }^{1}$ Seung Boo Yang,, ${ }^{2}$ Woong Hee Lee, ${ }^{2}$ Jae Hong Ahn, ${ }^{1}$ Dong Erk Goo, ${ }^{2}$ Nae Jin Han, ${ }^{2}$ \\ and Joon Young $\mathrm{Ohm}^{3}$ \\ ${ }^{1}$ Department of Radiology, Gangneung Asan Hospital, Gangneung, South Korea \\ ${ }^{2}$ Department of Radiology, Soonchunhyang University Hospital, Gumi, South Korea \\ ${ }^{3}$ Department of Radiology, Department of Radiology, Chungnam National University Hosiptal, Daejeon, South Korea \\ "Corresponding author: Seung Boo Yang, Department of Radiology, Soonchunhyang University Hospital, Gumi, South Korea, E-mail: ysbysb@sch.ac.kr
}

Received 2016 April 29; Revised 2016 August 02; Accepted 2016 August 16.

\begin{abstract}
Background: Central vein stenosis or occlusion is a common complication that can lead to significant morbidity and dysfunction of access in the hemodialysis patient. More lesions can develop over time, and preserving access becomes a challenge as life expectancy of the hemodialysis patient increases.

Objectives: The goal was to compare long-term results and determine the outcomes of open-cell stent versus closed-cell stent for central vein stenosis or occlusion in hemodialysis patients.

Patients and Methods: From 1997 to 2015, in 401 hemodialysis patients, stent placement for central vein stenosis or occlusion was performed if balloon angioplasty was unsatisfactory, due to elastic recoil or occurrence of restenosis within 3 months. When thrombus was present, primary stenting was performed. A total of 257 open-cell stents and 144 closed-cell stents were used. Angiographic findings including lesion site, central vein stenosis or occlusion, and presence of thrombosis and complication were evaluated. Primary patency rate and mean patency rate of the stent were compared between two stent groups by Kaplan-Meier survival analysis. Results: For the open-cell stent group, 159 patients were diagnosed as central vein stenosis and 98 were occlusion. For the closed-cell stent group, 78 were stenosis and 66 were occlusion. There were two complications for central migration and two for procedurerelated vein rupture. Open-cell stents and closed-cell stents had mean patency rates of $10.9 \pm 0.80$ months and $8.5 \pm 10.87$ months, respectively $(\mathrm{P}=0.002)$.

Conclusion: The open-cell stent is effective and its performance is higher than that obtained with the closed-cell stent for treating central vein stenosis or occlusion in hemodialysis patients.
\end{abstract}

Keywords: Dialysis, Veins, Angioplasty, Stents

\section{Background}

The trauma of passing a large dialysis catheter through the vein wall is an important initiating stimulus for the fibrin sheath and subsequent fibrosis in the central vein (1). Respirations, cardiac motion, and positional changes tend to move the indwelling catheter within the vein, and can probably damage the wall as well $(2,3)$. Subsequent creation of an ipsilateral arteriovenous (AV) access with the associated high flows, turbulence, and perivascular vibrations stimulate intimal hyperplasia and these sequence of events ultimately result in stenosis of the central vein (4, 5).

Surgical management options have high primary patency rates, but they are prone to significant morbidity associated with exposure of the deep veins, especially considering the poor health status of most hemodialysis patients
(6). Endovascular treatment options include percutaneous transluminal angioplasty (PTA) and percutaneous transluminal stenting (PTS).

Most studies on endovascular procedures for venous stenosis or occlusion in the hemodialysis patient have reported primary patency rates from 10 to $30 \%$ after 1 year (711). Published outcomes with stenting for central venous stenosis and occlusions have primarily utilized the Wallstent (Boston Scientific, Natick, MA, USA) with 12-month primary patency rates below 31\% (8, 10-12), though one study demonstrated 56\% patency (13). A study by Vogel and Parise (14) using the SMART stent (Cordis, Miami, FL, USA) demonstrated $67 \%$ primary patency for central venous stenosis at 12 months.

Depending on the density of the struts, stents can be classified as those with a closed-cell or an open-cell config- 
uration (15). Closed-cell stents are characterized by small free cell areas between the struts, whereas open-cell stents have larger uncovered gaps. Flexibility and scaffolding are key characteristics derived from stent designs (15). Closedcell stents are less flexible and may develop kinks and incomplete expansion (16). Conversely, stents with an opencell configuration conform best to angulated vessels or tortuous anatomy.

Carotid artery stenting with different designs and configurations are available, but direct comparisons of opencell versus closed-cell stents has rarely been performed in central vein stenosis or occlusions (16-18).

\section{Objectives}

The purpose of this study was to evaluate our outcomes following the use of an open-cell stent versus a closed-cell stent for patients with central vein stenosis or occlusions in hemodialysis patients and to compare long-term patency between the two groups retrospectively.

\section{Patients and Methods}

\subsection{Patients Group}

The records of 2418 hemodialysis patients who underwent endovascular treatment for central vein stenosis or occlusion at Gangneung Asan hospital and Soonchunhyang university hospital from 1997 to 2015 were reviewed. Symptoms included arm swelling and pain with venous hypertension. Patients with central vein stenosis or occlusions successfully treated with balloon angioplasty alone were excluded. A 70\% or greater stenotic lesion of the central veins with filling of the collateral veins was an indication for balloon angioplasty. Stent placement was performed only if conventional balloon angioplasty was unsatisfactory, due to elastic recoil ( $>30 \%$ residual stenosis and continued filling of collateral veins around the lesion) or occurrence of restenosis within 3 months after balloon angioplasty for the same lesion (19). When thrombus in the central vein was present, the treatment of choice was a primary stent placement.

Among them, 401 patients (200 males and 201 females; mean age, 59.17 years; range, 23 - 86) who underwent stent placement were enrolled in this study. Case data were retrospectively retrieved from radiographic reports, angiographic images, and medical records. Records were reviewed for the patient's age, sex, incidence of diabetes, hypertension, smoking, and age of dialysis access. Radiographic records were reviewed for a history of previous angioplasty for the same lesion, location of venous stenosis or occlusion, and length and diameter of stents employed.
The causes of chronic renal failure were hypertension (32.4\%), diabetes mellitus (32.2\%), glomerulonephritis (7\%), tuberculosis $(0.2 \%)$, systemic lupus erythematosus (0.2\%), pregnancy-induced intoxication (0.2\%), and unknown origins (27.8\%).

The clinical features of the patients whose central vein stenosis or occlusion was treated with an open-cell stent and those treated with a closed-cell stent are compared (Table 1).

\subsection{Procedure}

All patients underwent an initial diagnostic fistulography by $21 \mathrm{G}$ needle into the outflow vein. The access circuit was evaluated via contrast digital subtraction fistulography from arterial anastomosis to the right atrium. Intravenous (IV) fentanyl citrate and midazolam were used for sedation in patients who were agitated or who could not tolerate the pain during the procedure. All patients with thrombosis were given IV 5,000 IU of heparin during the procedure.

Two hundred fifty seven open-cell stents and 144 closed-cell stents were used. Design and prototype of stents are summarized in Table 2 . The stent used in each patient was based on product availability and physician preference.

Stent sizes varied from 10 to $24 \mathrm{~mm}$ in diameter, and 20 to $80 \mathrm{~mm}$ in length. Open-cell stents with a diameter of 10 to $14 \mathrm{~mm}$ were placed in the study population. In closed-cell stents, the diameter varied from 10 to $24 \mathrm{~mm}$. The stents were dilated post-deployment to the appropriate size of the vein in all cases. The diameter of the stent was determined after a review of baseline angiography results and the stent length required was based on the extent and location of the lesion so that both ends of the stent could be extended to the adjacent normal vein. Stents with a diameter 1 to $2 \mathrm{~mm}$ larger than that of the true vessel lumen were used for all devices.

\subsection{Data Analysis and Statistical Analysis}

The computerized access database was used to review all 2418 fistulography performed during the 14-year period from July 1997 to February 2011 retrospectively for central vein stenosis or occlusion in the hemodialysis patient.

Technical success was defined as a restoration of flow in the hemodynamic access with less than 30\% residual diameter stenosis for the underlying central venous lesion treated and decreased collateral circulation (19). Primary patency was defined as the time interval from initial stent insertion to the next percutaneous intervention for central venous stenosis or occlusion (19). All complications that occured within 30 days were considered procedure related 
Table 1. Patient Demographics ${ }^{\mathrm{a}}$

\begin{tabular}{|c|c|c|}
\hline Characteristics & Open-Cell Stent $(n=257)$ & Closed-Cell Stent $(n=144)$ \\
\hline Age (years \pm SD) & $60.6 \pm 12.3$ & $56.7 \pm 11.9$ \\
\hline Male/Female & $128 / 129$ & $72 / 72$ \\
\hline \multicolumn{3}{|l|}{ History } \\
\hline Diabetes mellitus & $94(37 \%)^{\mathrm{b}}$ & $35(24 \%)$ \\
\hline Hypertension & $190(73 \%)^{b}$ & $60(42 \%)$ \\
\hline Smoking & $10.5 \%$ & $10.9 \%$ \\
\hline Duration of CRF ( $y$ ) & $7.1 \pm 5.7^{\mathrm{b}}$ & $6.5 \pm 4.2$ \\
\hline \multicolumn{3}{|l|}{ Fistula } \\
\hline $\mathbf{R t} / \mathbf{L t}$ & $74 / 183$ & $45 / 99$ \\
\hline Age (m) & $48.4 \pm 50.5^{\mathrm{b}}$ & $31.3 \pm 31$ \\
\hline AVF/AVG & $141^{\mathrm{b}} / 116$ & $102 / 42$ \\
\hline Thrombosis (+) & $30(11.7 \%)$ & $12(8.3 \%)$ \\
\hline PTA Hx & $108(42 \%)$ & $57(39.6 \%)$ \\
\hline Central cath $\mathrm{Hx}$ & $146(56.8 \%)^{b}$ & $107(74.3 \%)$ \\
\hline
\end{tabular}

Table 2. Stent Design and Prototype

\begin{tabular}{|lc}
\hline Stent Design and Prototype & No. \\
\hline Closed-cell stents & 144 \\
\hline Wallstent (Boston Scientific, Natick, MA), & 31 \\
\hline Niti-S stent (Taewoong Med, Seoul, Korea) & 113 \\
\hline Open-cell stents & 257 \\
\hline Luminexx (Bard Peripheral, Murray Hill, NJ) & 27 \\
\hline SMART stent (Cordis, Miami lakes, FL) & 125 \\
\hline Zilver (Cook, Bloomington, IN) & 105 \\
\hline
\end{tabular}

(19). Procedure time was defined as the time interval from the start of percutaneous puncture through the final posttreatment angiogram (19). Clinical evaluation and fistulography were performed if symptoms recurred.

A statistics software package (SPSS, version 14.0, SPSS) was used for statistical analysis. Measured values were reported as percentage or means. Kaplan-Meier method was used to calculate the cumulative probability of patency and mean patency. For analysis of categorical variables, the $\chi^{2}$ test and t-test were used (Table 1). The log-rank test was used to compare the patency between the two groups. A P value $<0.05$ was considered statistically significant.

\section{Results}

\subsection{Patients Group}

When analyzing across both open-cell stents group and closed-cell stents group, we found that a history of diabetes, hypertension, duration of chronic renal failure, and history of previous catheter insertion were significant in the open-cell stents group (Table 1).

Considering the two groups collectively, the vessel most commonly treated was the innominate vein $(n=306)$, followed by the subclavian vein $(n=89)$, and jugular vein ( $n$ =6). In the open cell-stent group, 205 innominate veins, 46 subclavian veins, and six jugular veins were involved, and in the closed-cell stent group, 101 innominate veins and 43 subclavian veins were involved. The author found 159 central vein stenoses, and 98 central vein occlusions in the open-cell stent group, and 78 central vein stenoses, and 66 central vein occlusions in the closed-cell stent group (Table 3). There were 30 cases of thrombosis in the open-cell stent group, and 12 cases in the closed-cell stent group.

\subsection{Procedure}

The technical success rate was 99.3\% (398 of 401 procedures). One failure with an open-cell stent involved a successful stent placement, but coexistence of thrombosis in the graft site was not removed completely and the flow was 
Table 3. Location and Type of Lesions ${ }^{\mathrm{a}}$

\begin{tabular}{|c|c|c|c|c|c|}
\hline \multirow[t]{2}{*}{ Location } & \multicolumn{2}{|c|}{ Open-Cell Stent $(\mathrm{n}=\mathbf{2 5 7})$} & \multicolumn{2}{|c|}{ Closed-Cell Stent $(\mathrm{n}=144)$} & \multirow[t]{2}{*}{ Total } \\
\hline & Stenosis & Occlusion & Stenosis & Occlusion & \\
\hline Subclavian v & 28 & 18 & 16 & 27 & $89(22.2)$ \\
\hline Innominate $v$ & 125 & 80 & 62 & 39 & $306(76.3)$ \\
\hline Jugular v & 6 & 0 & 0 & 0 & $6(1.5)$ \\
\hline Total & 159 & 98 & 78 & 66 & 401 \\
\hline
\end{tabular}

Abbreviation: $v$, vein

${ }^{\mathrm{a}}$ Numbers in parentheses are percentage.

insufficient. Another unsuccessful patient with a closedcell stent was the result of incorrect stent positioning, thus creating a misplacement of the stent. One failure with the closed-cell stent was the result from stent collapse (Figure $1)$.

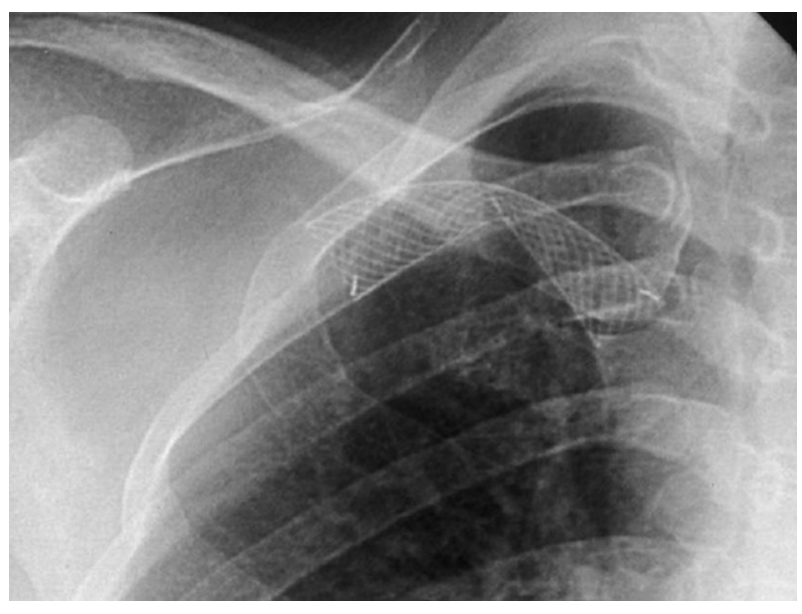

Figure 1. Technical failure case; A 46-year-old patient with radio-cephalic fistula. A fluoroscopic image shows collapsed closed-cell stent in the right subclavian vein and follow-up fistulogram shows more than $30 \%$ residual stenosis in the subclavian vein (not shown).

There were four cases of procedure-related complications. Two were complications from central migration of a stent during a placement that required an additional stent. A stent migration developed in two patients with closedcell stents, one in the superior vena cava (SVC) and one in the pulmonary artery. In one patient with stent migration to SVC during procedure, the stent was successfully removed. The other stent had migrated into the right pulmonary artery after one day as post-PTS, but there was failure of retrieval. There were two cases of procedure-related vein rupture. In one patient with axillary vein rupture, balloon tamponade for 5 minutes was successfully performed. In another patient with innominate vein rupture, a stent was placed. There were no procedure-related or periprocedural deaths.

Mean procedure time was 53.2 minutes (range, 14-220). The insertion of one stent was sufficient to cover the entire lesion in each procedure. The mean follow-up period was $8.8 \pm 9.97$ month (range, 1-75). Follow-up fistulography was performed in 282 patients and only 21 patients had undergone clinical follow-up. There were three cases of technical failures, one case of death during follow-up, and 94 cases of no follow-up.

\subsection{Data Analysis and Statistical Analysis}

For the open-cell stent group, the primary patency rate was $86.4 \%, 64.8 \%, 28.8 \%$, and $9.3 \%$ at $3,6,12$, and 24 months, respectively. For the closed-cell stent group, the primary patency rate was $69.1 \%, 38.7 \%, 16.0 \%$, and $6.5 \%$ at $3,6,12$, and 24 months, respectively. Open-cell stents and closed-cell stents had mean patency rates of $10.9 \pm 0.80$ months and $8.5 \pm 10.87$ months, respectively $(\mathrm{P}=0.002)$. The survival analysis of the primary patency rate for open-cell stent and closed-cell stent is show in Figure 2.

The mean patency rates in the open-cell stents group and closed-cell stents group are given in Table 4 by lesion site, lesion type (stenosis or occlusion), and presence of thrombosis. The mean patency rate for subclavian vein stenosis or occlusion was $11.1 \pm 1.66$ month in the open-cell stent group and $4.9 \pm 0.18$ months in the closed-cell stent group $(\mathrm{P}<.001)$. The mean patency rate for innominate vein stenosis or occlusion was $11.1 \pm 0.92$ months in the open-cell stent group and $10.1 \pm 1.50$ months in the closedcell stent group $(\mathrm{P}=0.15)$. The mean patency rate for central vein stenosis was $10.5 \pm 0.87$ months in the open-cell stent group and $8.0 \pm 1.11$ months in the closed-cell stent group $(\mathrm{P}=0.042)$. The mean patency rate for central vein occlusion was $11.9 \pm 1.59$ months in the open-cell stent group and $8.9 \pm 1.92$ months in the closed-cell stent group $(\mathrm{P}=0.020)$. In the case of thrombosis, the mean patency rate was 11.4 \pm 2.02 months in the open-cell stent group and $10.6 \pm 6.53$ months in the closed-cell stent group $(\mathrm{P}=0.153)$. In cases 




Figure 2. Primary patency rate of open-cell stent and closed-cell stent. Graph shows the patency rate of the central vein after placement of 257 open-cell stents and 144 closed-cell stents. Primary patency rate of open-cell stent group is significantly longer than that of closed-cell stent group $(\mathrm{P}=0.02)$ by Kaplan-Meier analysis.

without thrombosis, the mean patency rate was $10.9 \pm 0.85$ months in the open-cell stent group and $8.2 \pm 0.99$ months in the closed-cell stent group $(\mathrm{P}=0.006)$.

\section{Discussion}

Central vein stenosis or occlusion is a common complication of the chronic hemodialysis patient, resulting in considerable edema of the arm with vascular access that is unable to drain normally. Surgical repair of these central veins can be difficult. That is why the percutaneous approach is preferable to the surgical approach (20). Angioplasty alone may represent a reasonable option for the treatment of central venous lesions. Stents are thought to add a beneficial effect to angioplasty by limiting the elastic recoil present in compliant veins, excluding damaged and dissected intravascular tissues, and acting as an intravascular support to counteract extrinsic compression (12). This is especially relevant for the central venous lesion, described as having high elastic recoil and poor results with PTA alone (12). It is natural to expect that reports concerning PTA as the only management option would have lower patency rates.

Previous findings in the patency rates of central vein obstruction in PTS vary widely from ours. We believe that the main reasons for this variation are the different PTS protocols, types of stents, study populations, age of access, access thrombosis at the time of intervention, and veins treated $(8,10,12,21,22)$.

A stent can be classified as a closed-cell stent or an opencell stent, depending on the density of struts (15). Closed- cell stents are characterized by small free cell areas between struts, whereas open-cell stents have larger uncovered gaps (Figure 3) (23). Closed-cell stents with a small cell size have a dense, metallic mesh and therefore, may provide more effective plaque coverage and reduce the risk of particle embolization (16). However, closed-cell stents are known to be less flexible and more rigid and are more likely to be used in straight morphologies (16). In contrast, open-cell stents are flexible; kinked lesions are ideally treated with these stents (16).

New stents were designed to incorporate visibility, flexibility, and expandability, permitting the treatment of the most complex venous lesion through endovascular means. Potential advantages of this approach include its less invasive nature, safety, ability to be done on an outpatient basis, better preservation of native veins, and, most important, its association with greater patient satisfaction and less discomfort (12).

Previous studies using closed-cell stents (Wallstent, Boston Scientific, Natick, MA) have failed to demonstrate improved survival or patency compared with angioplasty $(7,11,12)$. Reports concerning the use of the Wallstent in central vein obstruction are common $(13,24,25)$. With Wallstents, technical success was between $96 \%$ and $100 \%$. Primary patency ranged from $42 \%$ to $84 \%$ at 6 months, but was less than $31 \%$ at 12 months in four studies $(8,10-12)$, with Haage et al. (13) demonstrating 56\% primary patency at 12 months. Unfortunately, no one has since reported results as successful as those that the Haage group did.

Early experience with open-cell stents (Zilver nitinol stent, Cook, Bloomington, IN, USA) for central venous occlusion appears to indicate that they confer longer midterm patency than historically observed results for central venous occlusion and central venous stenosis using Wallstents (22). In a study conducted by Vogel and Parise (14), use of the SMART stent demonstrated 67\% primary patency for central venous stenosis at 12 months. In a study performed by Rajan and Saluja (22), use of the Zilver nitinol stent (Cook, Bloomington, IN, USA) demonstrated 66.7\% primary patency for central venous stenosis at 6 and 12 months.

There have been two reports comparing the closed-cell stent with open-cell stent $(26,27)$. The authors of those reports reported no significant difference between the patency of the Wallstents and the nitinol-based Memotherm or Luminexx stent in their small groups $(26,27)$.

We have reported our large group study in stent treatment of central vein stenosis or occlusion with open-cell stent or closed-cell stent. Primary patency rates and clinical outcomes were comparable for the two-stent groups.

We found that the primary patency rate of open-cell stent was significantly higher than that of the closed-cell 
Table 4. Mean Patency Rate for Different Sites and Lesions ${ }^{\mathrm{a}}$

\begin{tabular}{|c|c|c|c|}
\hline & \multicolumn{2}{|c|}{ Mean Patency (m) } & \multirow[t]{2}{*}{ P Value } \\
\hline & Open-Cell Stent & Closed-Cell Stent & \\
\hline \multicolumn{4}{|l|}{ Lesion Site } \\
\hline Subclavian v & $11.1 \pm 1.66$ & $4.9 \pm 0.18$ & $<0.001^{b}$ \\
\hline Innominate v & $11.1 \pm 0.92$ & $10.1 \pm 1.5$ & 0.146 \\
\hline \multicolumn{4}{|l|}{ Lesion Type } \\
\hline Occlusion & $11.9 \pm 1.59$ & $8.9 \pm 1.92$ & $0.020^{\mathrm{b}}$ \\
\hline Stenosis & $10.5 \pm 0.87$ & $8.0 \pm 1.11$ & $0.042^{\mathrm{b}}$ \\
\hline \multicolumn{4}{|l|}{ Thrombosis } \\
\hline$(+)$ & $11.4 \pm 2.02$ & $10.6 \pm 6.53$ & 0.153 \\
\hline$(-)$ & $10.9 \pm 0.85$ & $8.2 \pm 0.99$ & $0.006^{\mathrm{b}}$ \\
\hline Overall & $10.9 \pm 0.798$ & $8.5 \pm 10.87$ & $0.002^{\mathrm{b}}$ \\
\hline
\end{tabular}

stent. The 6-month and 12-month primary patency rates with the open-cell stent were $64.8 \%$ and $28.8 \%$, respectively, and primary patency rates with closed-cell stent were $38.7 \%$ and $16.0 \%$, respectively. Open-cell stents and closed-cell stents had mean patency rates of $10.9 \pm 0.80$ months and $8.5 \pm 10.87$ months, respectively $(\mathrm{P}=0.002)$. The reported patency rate of $66.7 \%$ at 6 and 12 months following nitinol stent placement by Rajan and Saluja (22) might be the result of a small patient population $(n=6)$.

In this study, the mean patency rate of the subclavian vein with open-cell stent was $11.1 \pm 1.66$ months and the mean patency rate with closed-cell stent was $4.9 \pm 0.18$ months. There is a significant difference in the subclavian vein stenosis or occlusions between the open-cell stent group and closed-cell stent group in this study $(\mathrm{P}<0.001)$. Our results might be related to characteristics of the opencell stent, including flexibility, radial strength, and expansibility. The open-cell stent has physical properties that differ from those of the closed-cell stent. The closed-cell stent appears to have problems with its shortening and migrating during respiration (Figure 4$)(8,10,11,13)$.

The efficacy of stent deployment appears to vary by the vascular location of the stenotic lesion. Recently, nitinol stents have been introduced and have several physical characteristics that may confer longer patency compared with Wallstents (28). Nitinol, an alloy of nickel and titanium, exists in two temperature-dependent forms, which are predetermined by adjusting the ratio of nickel and titanium and through high-temperature heating. When nitinol assumes its higher-temperature form, it expands to its predetermined size and becomes more rigid. Nitinol is also superelastic in that it will deform its shape but return to its original configuration when an external force is applied and then removed (29-31). Shape memory and superelasticity allow for an improved apposition of the stent along the vessel wall and maintenance of radial strength (Figure 5).

The Wallstent is constructed of Elgiloy, the free ends are sharp and capable of embedding into the vessel wall. Eccentric loading of the Wallstent such as that produced by a stenosis results in concentric narrowing beyond the point at which the load is applied, making it susceptible to reduced wall contact and decreased radial strength (32). Poor or incomplete wall contact appears to be a risk factor for in-stent stenosis $(33,34)$, and decreased radial strength (29). In this study, there was a case of incomplete wall contact in the closed-cell stent group for stenosis at the left innominate vein (Figure 6). Closed-cell stent has also been observed to migrate and foreshorten in central venous segments (Figure 4$)(8,10,11,13)$. In addition, two cases of central stent migration were observed in patients with closedcell stent in this study.

Open-cell stents are structured to allow for minimal foreshortening. Open-cell stents have become standard practice over closed-cell stents, mainly due to easier and more precise placement, non-shortening of the open-cell stents, and a longer vascular patency. The superelasticity and shape-memory characteristics of the nitinol stent improve flexibility, which also improve opposition to the vessel wall (Figure 5).

Depending on the density of the bridges between the different rings, nitinol stents can be classified into stents 


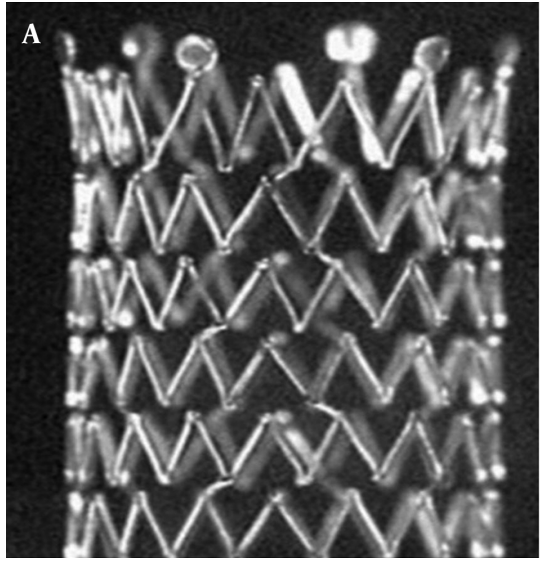

B

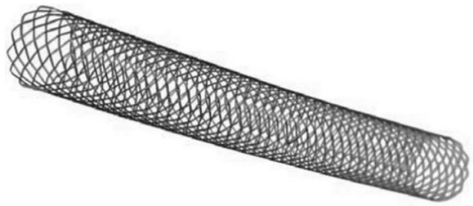

Figure 3. Examples of an open-cell stent (A) and a closed-cell stent (B)
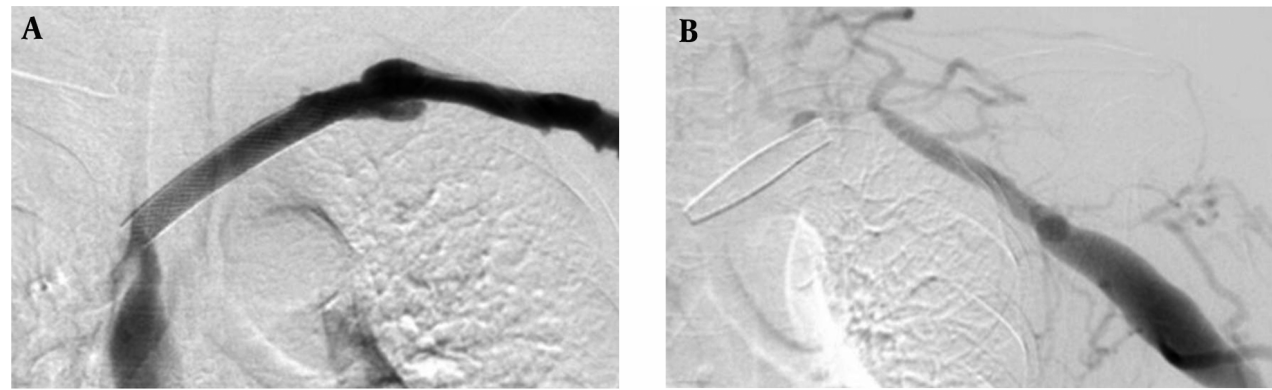

Figure 4. A 55-year-old patient with brachio-cephalic fistula. A, Closed-cell stent is placed at left innominate vein. B, Fistulogram obtained 7 months after stenting shows shortening of the stent.
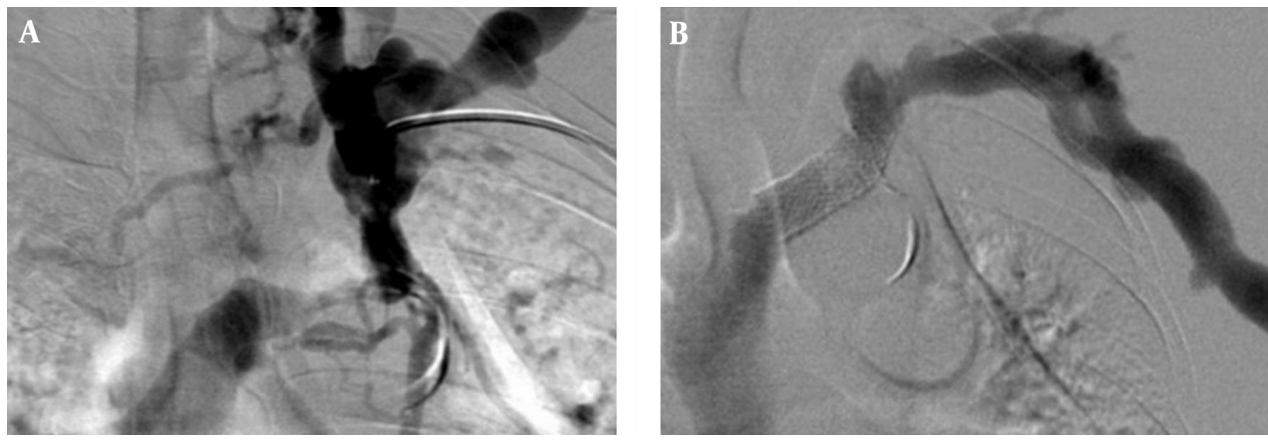

Figure 5. A 46-year-old patient with brachio-basilic fistula. A, Fistulogram shows segmental stenosis with severe tortuosity and pronounced collateral flow at left innominate vein. B, Fistulogram shows restoration of flow and vanishing of collateral vessels after open-cell stent placement.

with a closed-cell or an open-cell configuration. Flexibility and scaffolding are key characteristics derived from stent design (15). Flexibility depends on the stent's ability to conform the vessel tortuosity in the deployed state. Closed-cell stents are rigid, less flexible and may develop kinks and incomplete deployment in the tortuous vessel. Conversely, stents with an open-cell configuration conform best to angulated vessels or tortuous anatomy. Stents with a flexible and conformable open-cell configuration are preferred in vessels that are angulated or have a tortuous anatomy.

Patients in this study group did not experience any major morbidity or mortality, except for two cases of stent mi- 

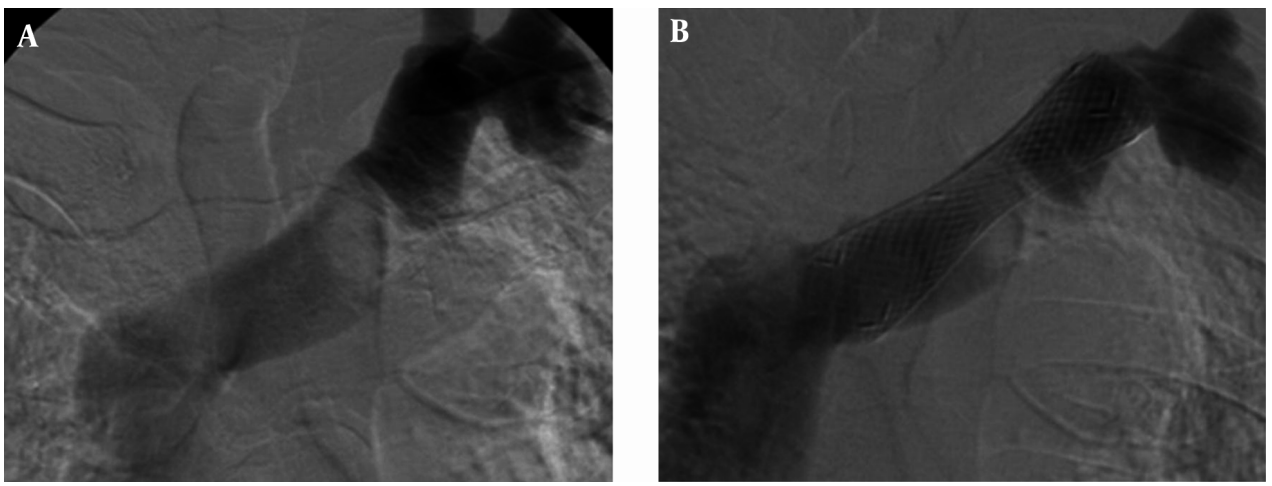

Figure 6. A 71-year-old-man with radio-cephalic fistula and left upper arm swelling. A, Fistulogram shows stenosis in left innominate vein. B, Fistulogram obtained after closed-cell stent placement shows incomplete contact of the stent to the vessel wall.

gration and minor complications.

There are several limitations to the present study. First, this study was retrospective and had mixed group patients among those with or without a history of hypertensio, diabetes mellitus, peripheral vascular disease, and use of tobacco, so their possible effects on patency rates could not be assessed. Although a history of diabetes, hypertension, duration of chronic renal failure and history of previous catheter insertion is more common in the open-cell stents group, the open-cell stent is more effective for treatment of central vein stenosis or occlusion in hemodialysis patients.

Second, differences in baseline and lesion characteristics may have influenced the observed results. It is unknown what role concurrent stenosis along the access circuit may have on patency following intervention for central venous occlusion.

In conclusion, the open-cell stent is effective for the treatment of central vein stenosis or occlusion in hemodialysis patients who have incomplete PTA results. These results suggest the use of open-cell stent for the treatment of central vein stenosis or occlusion in hemodialysis patients.

\section{Acknowledgments}

There is no acknowledgement.

\section{Footnotes}

Authors' Contributions: Seung Boo Yang and Chae Hoon Kang were guarantors of integrity of the entire study. All authors contributed to this study; statistical analysis was done by Chae Hoon Kang.

Conflict of Interest: There is no conflict of interest.
Funding/Support: No financial assistance was obtained from any organization or company. The project was funded by the institution itself.

\section{References}

1. Gray RJ, Dolmatch BL, Buick MK. Directional atherectomy treatment for hemodialysis access: early results. J Vasc Interv Radiol. 1992;3(3):497-503. [PubMed: 1515722]

2. Kowalski CM, Kaufman JA, Rivitz SM, Geller SC, Waltman AC. Migration of central venous catheters: implications for initial catheter tip positioning. J Vasc Interv Radiol. 1997;8(3):443-7. [PubMed: 9152919].

3. Nazarian GK, Bjarnason H, Dietz CJ, Bernadas CA, Hunter DW. Changes in tunneled catheter tip position when a patient is upright. J Vasc Interv Radiol. 1997;8(3):437-41. [PubMed: 9152918].

4. Fillinger MF, Reinitz ER, Schwartz RA, Resetarits DE, Paskanik AM, Bruch D, et al. Graft geometry and venous intimal-medial hyperplasia in arteriovenous loop grafts. J Vasc Surg. 1990;11(4):556-66. [PubMed: 2182916].

5. Middleton WD, Erickson S, Melson GL. Perivascular color artifact: pathologic significance and appearance on color Doppler US images. Radiology. 1989;171(3):647-52. doi: 10.1148/radiology.171.3.2655000. [PubMed: 2655000].

6. Ozyer U, Harman A, Yildirim E, Aytekin C, Karakayali F, Boyvat F. Longterm results of angioplasty and stent placement for treatment of central venous obstruction in 126 hemodialysis patients: a 10-year single-center experience. AJR Am J Roentgenol. 2009;193(6):1672-9. doi: 10.2214/AJR.09.2654. [PubMed: 19933663].

7. Quinn SF, Schuman ES, Demlow TA, Standage BA, Ragsdale JW, Green GS, et al. Percutaneous transluminal angioplasty versus endovascular stent placement in the treatment of venous stenoses in patients undergoing hemodialysis: intermediate results. J Vasc Interv Radiol. 1995;6(6):851-5. [PubMed: 8850659].

8. Vorwerk D, Guenther RW, Mann H, Bohndorf K, Keulers P, Alzen G, et al. Venous stenosis and occlusion in hemodialysis shunts: follow-up results of stent placement in 65 patients. Radiology. 1995;195(1):140-6. doi: 10.1148/radiology.195.1.7892456. [PubMed: 7892456].

9. Ozkan B, Gungor D, Yildirim UM, Harman A, Ozen O, Aytekin C. Endovascular stent placement of juxtaanastomotic stenosis in native arteriovenous fistula after unsuccessful balloon angioplasty. Iran J Radiol. 2013;10(3):133-9. doi: 10.5812/iranjradiol.11386. [PubMed: 24348598]. 
10. Gray RJ, Horton KM, Dolmatch BL, Rundback JH, Anaise D, Aquino $\mathrm{AO}$, et al. Use of Wallstents for hemodialysis access-related venous stenoses and occlusions untreatable with balloon angioplasty. Radiology. 1995;195(2):479-84. doi: 10.1148/radiology.195.2.7724770. [PubMed: 7724770].

11. Vesely TM, Hovsepian DM, Pilgram TK, Coyne DW, Shenoy S. Upper extremity central venous obstruction in hemodialysis patients: treatment with Wallstents. Radiology. 1997;204(2):343-8. doi: 10.1148/radiology.204.2.9240518. [PubMed: 9240518].

12. Oderich GS, Treiman GS, Schneider P, Bhirangi K. Stent placement for treatment of central and peripheral venous obstruction: a longterm multi-institutional experience. J Vasc Surg. 2000;32(4):760-9. doi: 10.1067/mva.2000.107988. [PubMed: 11013040].

13. Haage P, Vorwerk D, Piroth W, Schuermann K, Guenther RW. Treatment of hemodialysis-related central venous stenosis or occlusion results of primary Wallstent placement and follow-up in 50 patients. Radiology. 1999;212(1):175-80. doi: 10.1148/radiology.212.1.r99jl21175. [PubMed: 10405739]

14. Vogel PM, Parise C. SMART stent for salvage of hemodialysis access grafts. J Vasc Interv Radiol. 2004;15(10):1051-60. doi: 10.1097/01.RVI.0000129915.48500.DC. [PubMed: 15466790].

15. Stoeckel D, Bonsignore C, Duda S. A survey of stent designs. Minim Invasive Ther Allied Technol. 2002;11(4):137-47. doi: 10.1080/136457002760273340. [PubMed:16754063].

16. Schillinger M, Gschwendtner M, Reimers B, Trenkler J, Stockx L, Mair J, et al. Does carotid stent cell design matter?. Stroke. 2008;39(3):905-9. doi:10.1161/STROKEAHA.107.499145. [PubMed: 18239162].

17. Pierce DS, Rosero EB, Modrall JG, Adams-Huet B, Valentine RJ, Clagett GP, et al. Open-cell versus closed-cell stent design differences in blood flow velocities after carotid stenting. J Vasc Surg. 2009;49(3):602-6. doi: 10.1016/j.jvs.2008.10.016. [PubMed: 19268763].

18. Timaran $\mathrm{CH}$, Rosero EB, Higuera A, Ilarraza A, Modrall JG, Claget GP. Randomized clinical trial of open-cell vs closed-cell stents for carotid stenting and effects of stent design on cerebral embolization. J Vasc Surg. 2011;54(5):1310-6. doi: 10.1016/j.jvs.2011.05.013. [PubMed: 21723064].

19. Gray RJ, Sacks D, Martin LG, Trerotola SO, Society of Interventional Radiology Technology Assessment C. Reporting standards for percutaneous interventions in dialysis access. J Vasc Interv Radiol. 2003;14(9 Pt 2):S433-42. [PubMed: 14514859]

20. Jindai KK, Ethier JH, Lindsay RM, Barre PE, Kappel JE, Carlisle E, et al. Clinical practice guidelines for vascular access. Am J Kidney Dis. 1999;10:S297-305.

21. Ponec D, Jaff MR, Swischuk J, Feiring A, Laird J, Mehra M, et al. The Nitinol SMART stent vs Wallstent for suboptimal iliac artery angioplasty: CRISP-US trial results. J Vasc Interv Radiol. 2004;15(9):911-8. doi: 10.1097/01.RVI.0000140935.45313.35. [PubMed:15361558].

22. Rajan DK, Saluja JS. Use of nitinol stents following recanalization of central venous occlusions in hemodialysis patients. Cardiovasc Intervent Radiol. 2007;30(4):662-7. doi: 10.1007/s00270-007-9083-9. [PubMed: 17533532]

23. Bosiers M, de Donato G, Deloose K, Verbist J, Peeters P, Castriota $\mathrm{F}$, et al. Does free cell area influence the outcome in carotid artery stenting?. Eur J Vasc Endovasc Surg. 2007;33(2):135-41. doi: 10.1016/j.ejvs.2006.09.019. [PubMed: 17097897].

24. Bakken AM, Protack CD, Saad WE, Lee DE, Waldman DL, Davies MG. Long-term outcomes of primary angioplasty and primary stenting of central venous stenosis in hemodialysis patients. J Vasc Surg. 2007;45(4):776-83. doi: 10.1016/j.jvs.2006.12.046. [PubMed: 17398386].

25. Aytekin C, Boyvat F, Yagmurdur MC, Moray G, Haberal M. Endovascular stent placement in the treatment of upper extremity central venous obstruction in hemodialysis patients. EurJ Radiol. 2004;49(1):815. doi: 10.1016/S0720-048X(02)00370-4. [PubMed: 14975496].

26. Maskova J, Komarkova J, Kivanek J, Danes J, Slavikova M. Endovascular treatment of central vein stenoses and/or occlusions in hemodialysis patients. Cardiovasc Intervent Radiol. 2003;26(1):27-30. doi: 10.1007/s00270-002-1960-7. [PubMed: 12491016].

27. Maya ID, Saddekni S, Allon M. Treatment of refractory central vein stenosis in hemodialysis patients with stents. Semin Dial. 2007;20(1):78-82. doi: 10.1111/j.1525-139X.2007.00246.x. [PubMed: 17244127].

28. Clark TW. Nitinol stents in hemodialysis access. J Vasc Interv Radiol. 2004;15(10):1037-40. doi: 10.1097/01.RVI.0000136029.88286.48. [PubMed: 15466787].

29. Dyet JF, Watts WG, Ettles DF, Nicholson AA. Mechanical properties of metallic stents: how do these properties influence the choice of stent for specific lesions?. Cardiovasc Intervent Radiol. 2000;23(1):4754. [PubMed: 10656906].

30. Duda SH, Wiskirchen J, Tepe G, Bitzer M, Kaulich TW, Stoeckel D, et al. Physical properties of endovascular stents: an experimental comparison.J Vasc Interv Radiol. 2000;11(5):645-54. [PubMed: 10834499].

31. Shabalovskaya SA. On the nature of the biocompatibility and on medical applications of NiTi shape memory and superelastic alloys. Biomed MaterEng. 1996;6(4):267-89. [PubMed: 8980835].

32. Flueckiger F, Sternthal H, Klein GE, Aschauer M, Szolar D, Kleinhappl G. Strength, elasticity, and plasticity of expandable metal stents: in vitro studies with three types of stress.JVasc Interv Radiol. 1994;5(5):745-50. [PubMed: 8000124].

33. Rogers C, Edelman ER. Endovascular stent design dictates experimental restenosis and thrombosis. Circulation. 1995;91(12):2995-3001. [PubMed: 7796511].

34. Trerotola SO, Fair JH, Davidson D, Samphilipo MI, Magee CA. Comparison of Gianturco Z stents and Wallstents in a hemodialysis access graft animal model. J Vasc Interv Radiol. 1995;6(3):387-96. [PubMed: $7647440]$ 